\title{
KINERJA KERJA PEGAWAI DITINJAU DARI ASPEK KOMPETENSI DAN DISIPLIN KERJA DI DINAS PENDIDIKAN PEMUDA DAN OLAHRAGA KABUPATEN SIKKA
}

\author{
Cicilia Ayu Wulandari Nuwa ${ }^{1}$, Imelda Virgula Wisang ${ }^{2}$, \\ Yoseph Darius Purnama Rangga ${ }^{3}$, Vinsensius Ama Muda ${ }^{4}$, \\ Viktor Eko Transilvanus ${ }^{5}$ \\ Universitas Nusa Nipa Maumere, Flores 1,2,3,4,5 $^{\text {(1) }}$ \\ ciciliaayuwulandari@gmail.com ${ }^{1}$,
}

\begin{abstract}
ABSTRAK
Penelitian ini bertujuan untuk menganalisis pengaruh kompetensi dan disiplin kerja terhadap kinerja kerja pegawai di Dinas Pendidikan Pemuda dan Olahraga Kabupaten Sikka. Penelian ini menggunakan sampel sebanyak 57 pegawai sebagai responden. Jenis penelitian yang digunakan adalah penelitian kuantitatif.Sedangkan metode yang digunakan adalah sampling jenuh.Hasil penelitian menunjukkan bahwa persamaan regresi linier berganda pada penelitian ini diketahui bahwa $\mathrm{Y}=6,306+0,076 \mathrm{X}_{1}+0,696 \mathrm{X}_{2}$ dimana Kompetensi $(\mathrm{X} 1)$, tidak berpengaruh secara parsial terhadap Kinerja Kerja Pegawai (Y). Sedangkan Disiplin Kerja berpengaruh secara parsial terhadap Kinerja Kerja Pegawai (Y) Dan variabel Kompetensi (X1) dan Disiplin Kerja (X2) berpengaruh secara simultan terhadap KinerjaKerja Pegawai(Y) Dinas Pendidikan Pemuda dan Olahraga Kabupaten Sikka.
\end{abstract}

Kata Kunci : Kompetensi,Disiplin Kerja, dan Kinerja Kerja Pegawai

\begin{abstract}
The research aims to analyse the influence of competence and work discipline on the work performance of the staff at the Youth and Sports Education office in Sikka district. The study used a sample of 57 employees as respondents. The type of research used is quantitative research. While the method used is sampling saturation. The results showed that multiple linear regression equations in the study were known that $Y=6.306+0.076 X 1+0.696 X 2$ where competence $(X 1)$, did not have a partial effect on employee work performance $(Y)$. Meanwhile, the working discipline partially affects the employee's work performance $(Y)$ and competency variables $(X 1)$ and work discipline $(X 2)$ simultaneously influence the work performance of the staff $(Y)$ of the Youth and Sports Education Office of Sikka District.
\end{abstract}

Keywords: Competence, Work Discipline, and Employee Work Performance

\section{PENDAHULUAN}

Manajemen sumber daya manusia adalah suatu ilmu atau cara bagaimana mengatur hubungan dan peranan sumber daya yang dimiliki oleh individu secara efisien dan efektif, serta dapat digunakan secara maksimal sehingga tercapai tujuan bersama dalam sebuah organisasi. Manajemen sumber daya manusia 
mempunyai fungsi operasional yaitu menilai dan mengembangkan sumber daya manusia, yang salah satu aktivitasnya adalah menilai kinerja pegawai. Kinerja pegawai merupakan hasil kerja seorang karyawan selama periode tertentu dibandingkan dengan berbagai kemungkinan, misalnya: standar, target ,sasaran, kriteria yang ditentukan dan disepakati. Akumulasi dari setiap kinerja pegawai akan menentukan kinerja keseluruhan dari organisasi.

Kinerja organisasi adalah hasil kerja yang dicapai oleh organisasi dalam hal ini organisasi dapat mencapai target unggul sesuai dengan yang di harapkan. Namun sesuai dengan data informasi laporan penyelenggaraan pemerintah daerah kabupaten sikka dan data capaian kinerja dinas pendidikan pemuda dan olahraga menyatakan bahwa banyak program program dari Dinas Pendidikan Pemuda dan Olahraga yang belum mencapai target. Berdasarkan pengamatan dan wawancara dengan Sekertaris dan beberapa pegawai di Dinas Pendidikan Pemuda dan Olahraga Kabupaten Sikka diperoleh keterangan bahwa tidak tercapainya target yang ditetapkan karenapelaksanaan dari program-program yang sudah ditetapkan tidak sesuai dengan perencanaan.

Simanjuntak (2011) menyatakan bahwa kinerja suatu perusahaan atau organisasi adalah akumulasi kinerja semua individu yang bekerja didalamnya. Dengan kata lain, upaya peningkatan kinerja perusahaan adalah melalui peningkatan kinerja masing-masing individu. Berdasarkan pendapat ini menunjukan bahwa kinerja Dinas Pendidikan Pemuda dan Olahraga Kabupaten Sikka merupakan akumulasi dari kinerja Pegawai yang ada saat ini. Kinerja Pegawai yang menurun tidak terjadi dengan sendirinya tetapi ada faktor-faktor yang mempengaruhi. Faktor-faktor tersebut adalah kompetensi dan disiplin pegawai.

Kompetensi merupakan perpaduan dari pengetahuan, ketrampilan, nilai dan sikap yang direfleksikan dalam kebiasaan berpikir dan bertindak. Kompetensi digunakan untuk mendeskripsikan kemampuan profesional yaitu kemampuan untuk menunjukkan pengetahuan dan konseptualisasi pada tingkat yang lebih tinggi. Kompetensi ini dapat diperoleh melalui pendidikan, pelatihan dan pengalaman lain sesuai tingkat kompetensinya. Kompetensi pegawai Dinas Pendidikan Pemuda dan Olahraga Kabupaten Sikka, terukur dari pendidikan formal dan keterampilan teknis. Pendidikan formal berhubungan dengan latar belakang atau jenjang pendidikan formal yang pernah dilalui. Ketrampilan teknis berhubungan dengan pelatihan yang pernah diikuti pegawai sesuai dengan bidang teknis. Jumlah pegawai di Dinas Pendidikan Pemuda dan Olahraga Kabupaten Sikka berjumlah 57 yang terdiri dari 56 orang PNS dan 1 orang pegawai honorer namun $50 \%$ dari total jumlah pegawai tersebut masih memiliki tingkat kualifikasi pendidikan SMA hal ini menunjukan rendahnya kompetensi pegawai dalam organisasi.

Berdasarkan pengamatan wawancara dengan Sekertaris dan beberapa pegawai di Dinas Pendidikan Pemuda dan Olahraga Kabupaten Sikkayang 
dilakukan peneliti menunjukan kondisi sebagai berikut : (1) Pegawai tidak memiliki keterampilan dan sikap kerja dalam memecahkan masalah yang berorientasi pada efisiensi, produktivitas, mutu dan kepedulian terhadap dampak lingkungan; (2) rendahnya kemampuan pegawai untuk membangun komunikasi yang efektif antar unit untuk menunjang keberhasilan tugas; (3) Rendahnya keterampilan dan sikap pegawai untuk mencari cara-cara baru dalam menyelesaikan pekerjaan.Selain kompetensi pegawai, disiplin kerja juga merupakan salah satu faktor yang sangat menentukan kinerja pegawai Dinas Pendidikan Pemuda dan Olahraga. Untuk mewujudkan pegawai negeri sipil yang handal, profesional, bermoral dan berkinerja, mutlak diperlukan peraturan disiplin pegawai yang dapat dijadikan pedoman dalam menegakkan disiplin, sehingga dapat menjamin terpeliharanya tata tertib dan kelancaran pelaksanaan tugas serta dapat mendorong pegawai negeri sipil untuk lebih produktif berdasarkan sistem karier dan sistem prestasi kerja. Peraturan Pemerintah No. 53 Tahun 2010 Tentang Disiplin Pegawai Negeri Sipil pasal 1 menyatakan bahwa

Disiplin Pegawai Negeri Sipil adalah kesanggupan Pegawai Negeri Sipil untuk menaati kewajiban dan menghindari larangan yang ditentukan dalam peraturan perundang-undangan dan/atau peraturan kedinasan yang apabila tidak ditaati atau dilanggar dijatuhi hukuman disiplin. Berdasarkan Undang-undang No. 53 Tahun 2010 tentang disiplin Pegawai Negeri Sipil, serta pengamatan dan wawancara dengan sekertaris dan beberapa pegawai di Dinas Pendidikan Pemuda dan OlahragaKabupaten Sikka yang dilakukan peneliti menunjukan kondisi sebagai berikut : (1) banyak Pegawai yang sering terlambat masuk kantor. Jam masuk kantor adalah 07.30 WITA, namun biasanya pegawai terlambat sekitar 10 sampai 20 menit, (2) ada pegawai yang datang tepat waktu namun tidak langsung melakukan pekerjaan melainkan mengobrol di luar kantor. (3) banyak pegawai yang menghabiskan waktu diluar kantor meskipun jam istirahat telah selesai, (4) ada beberapa pegawai yang tidak menyelesaikan tugas yang diembannya dengan alasan kekurangan fasilitas.

Mangkuprawira (2007) menyatakan bahwa disiplin kerja sangat mempengaruhi kinerja karyawan, hal ini disebabkan karena disiplin merupakan bentuk-bentuk latihan bagi karyawan dalam melaksanakan aturan-aturan perusahaan. Semakin disiplin pegawai semakin tinggi produktivitas kerja karyawan dan kinerja perusahaan. Disiplin kerja pada pegawai sangat dibutuhkan, karena apa yang menjadi tujuan organisasi akan sukar dicapai bila tidak ada disiplin kerja.Dilihat dari permasalahan di atas maka kinerja menjadi hal yang penting sebagai ukuran untuk meningkatkan tumbuh kembangnya sebuah organisasi. Dalam meningkatan kinerja pegawai pada Dinas Pendidikan Pemuda dan Olahraga Kabupaten Sikka perlu memperhatikan proses menejemen sumber daya manusia yang meliputi antara lain kompetensi, dan disiplin. Apabila kompetensi dan disiplin dilaksanakan dengan baik, maka organisasi tersebut akan berjalan dengan baik pula. 
Terdapat beberapa penelitian mengenai pengaruh kompetensi dan disiplin kerja terhadap kinerja kerja pegawai yaitu penelitian yang diakukan oleh Hamlan (2015) kompetensi, disiplin dan kompensasi berpengaruh secara signifikan terhadap kinerja kerja pegawai. Hasil penelitian yang dilakukan oleh Tony, et.al (2016) kompetensi dan disiplin kerja berpengaruh secara positif dan signifikan terhadap kinerja kerja pegawai.

Penelitian yang berbeda juga dilakukan oleh Boby et.al (2020) kepemimpinan diri dan disiplin berpengaruh secara positif dan signifikan terhadap kinerja pegawai. Hasil penelitian yang dilakukan oleh Epa (2020) kompetensi guru dan kepemimpinan kepala sekolah berpengaruh positif terhadap kinerja guru. Uswatun (2019) pelatihan dan disiplin kerja berpengaruh positif terhadap kinerja karyawan. Saputra (2016) disiplin mempunyai pengaruh yang positif dan signifikan terhadap kinerja karyawan sedangkan kompetensi mempunya pengaruh yang positif namun tidak signifikan terhadap Kinerja Karyawan. Namun pada penelitian ini focus pada kinerja pegawai ditinjau dari aspek kompetensi dan disiplin kerja di Dinas Pendidikan Pemuda dan Olahraga Kabupaten Sikka.

\section{METODEPENELITIAN}

Jenis Penelitian ini termasuk jenis penelitian kausalitas, dengan pendekatan kuantitatif yaitu penelitian yang ingin mencari hubungan sebab akibat antar variabel, kompetensi, disiplinkerja terhadap kinerja pegawai.Populasi dalam penelitian ini adalah pegawai Dinas Pedidikan Pemuda dan Olahraga Kabupaten Sikka sebanyak 57 orang. Adapun teknik analis data yang diperlukan dalam penelitian ini adalah: 1) analisis deskriptif, 2) analisis statistik inferensial (uji multikolinearitas, uji heterokedastisitas, uji normalitas, uji linearitas), 3) analisi regresi linear berganda, 4) uji hipotesis

\section{HASII PENELITIAN}

\section{Uji Validitas}

Hasil analisis uji validitas menunjukkan pada seluruh item pertanyaan untuk variabel kinerja, kompetensi , dan disiplin kerja mempunyai nilai koefisien korelasi lebih besar dari 0,3 sehingga dinyatakan valid. Dengan demikian maka pernyataan-pernyataan yang diajukan dalam kuesioner penelitian ini dapat digunakan untuk mengukur variabel penelitian.

\section{Uji Reliabilitas}

Hasil uji reliabilitas variabel kompetensi, disiplin dan kinerja pegawai pada Tabel 4.6 menunjukkan nilai Cronbach's Alpha melebihi persyaratan minimal 0,6. Selanjutnya nilai Cronbach's Alpha if Item Deleted pada variabel kompetensi, disiplin dan kinerja pegawai lebih rendah dari nilai Cronbach's Alpha, maka butir atau item tersebut tidak dihilangkan atau direvisi. Dengan demikian dapat dikatakan bahwa semua kuesioner dari kedua variabel ini adalah reliabel 
sehingga dapat digunakan untuk analisis data selanjutnya.

\section{Uji Regresi Linear Berganda}

Pengujian hipotesis yang digunakan dalam penilitian adalah dengan menggunakan analisis regresilinear berganda. Rumus persamaan regresi linear berganda adalah sebagai berikut :

$$
Y=6,306+0,076 X_{1}+0,696 X_{2}
$$

Model regresi yang digunakan adalah sebagai berikut :

Tabel 1

Hasil Analisis Linear Berganda

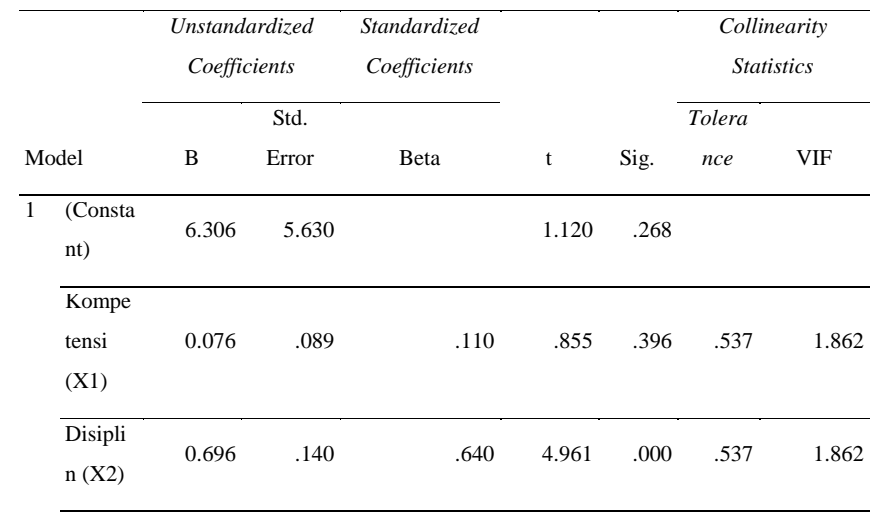

Kinerja Karyawan $=6,306+$ 0,076 Kompetensi + 0,696 Disiplin Kerja. Berdasarkan persamaan regresi di atas, maka interpretasi untuk konstanta dan masing-masing koefisien regresi dapat diuraikan sebagai berikut :

1. Konstanta (bo) : 6,306

Angka atau konstanta ini menjelaskan bahwa jika semua variabel bebas, dalam hal ini, yaitu variabel kompetensi pegawai $\left(\mathrm{X}_{1}\right)$, dan disiplin kerja $\left(\mathrm{X}_{2}\right)$ diasumsikan konstan atau perubahannya nol, maka kinerja pegawai(Y) sudah sebesar 6,306.

2. Koefisien Regresi $X_{1}\left(b_{1}\right): 0,076$

Koefisien regresi ini dapat dijelaskan bahwa jika variabel disiplin kerja $\left(\mathrm{X}_{2}\right)$ dianggap konstan atau tetap, maka apabila terjadi perubahan (kenaikan) pada variabel kompetensi pegawai $\left(\mathrm{X}_{1}\right)$ sebesar satu satuan, akan mengakibatkan terjadi kenaikan perubahan pada variabel kinerja pegawai (Y) sebesar 0,076; Demikian juga sebaliknya jika terjadi penurunan pada variabel kompetensi pegawai $\left(\mathrm{X}_{1}\right)$ sebesar satu satuan akan mengakibatkan terjadi penurunan pada kinerja pegawai (Y) sebesar 0,076 satuan.

3. Koefisien Regresi $X_{2}\left(b_{2}\right): 0,696$

Koefisien regresiini dapat dijelaskan bahwa jika variabel kompetensi pegawai $\left(\mathrm{X}_{1}\right)$ dianggap konstan atau tidak berubah, maka apabila terjadi perubahan (kenaikan) pada variabel disiplin kerja $\left(\mathrm{X}_{2}\right)$ sebesar satu satuan akan 
mengakibatkan terjadi kenaikan Kinerja Pegawai (Y) sebesar 0,696. Demikian juga sebaliknya jika terjadi penurunan pada variabel disiplin kerja $\left(\mathrm{X}_{2}\right)$ sebesar satu satuan akan mengakibatkan terjadi penurunan kinerja pegawai (Y) sebesar 0,696 satuan.

\section{Koefisien Determinasi Hipotesis}

Adjusted $R$ Square dinotasikan dengan $R^{2}$ merupakan nilai koefisien determinasi terkoreksi yang menyesuaikan $R^{2}$ dengan cara membagi tiap sum of square dengan derajat bebas masing-masing.

Tabel 2

Uji Koefisien Determinasi

\begin{tabular}{cccr}
\hline \multicolumn{4}{c}{ Model Summary $^{\mathbf{b}}$} \\
\hline & \multicolumn{1}{c}{ Adjusted $R$} & Std. Error of \\
$\mathrm{R}$ & Square & Square & the Estimate \\
\hline $0,719^{\mathrm{a}}$ & 0,517 & 0,500 & 9.80368 \\
\hline
\end{tabular}

Tabel 2 menunjukan nilai koefisien determinasi $\left(\mathrm{R}^{2}\right)$ sebesar 0,517yang berarti bahwa kontribusi ke 2 variabel bebas dalam penelitian ini yang terdiri atas : kompetensi, dan disiplin kerja terhadap variasi naik turunnya kinerja pegawai Dinas Pendidikan Pemuda dan Olahraga Kabupaten Sikka sebesar 51,7\%. Sedangkan sisanya sebesar 48,3\% dijelaskan oleh variabel-variabel lain yang tidak diikutsertakan dalam model penelitian ini.

\section{Pengujian Hipotesis Secara Simultan (Uji F)}

Pengujian statistik F pada dasarnya menunjukan apakah semua variabel bebas yang dimasukkan dalam model mempunyai pengaruh secara simultan terhadap variabel dependen.

Tabel 3

Uji Simultan

\begin{tabular}{crrrr}
\hline $\begin{array}{l}\text { Sum of } \\
\text { Squares }\end{array}$ & df & Mean Square & F & Sig. \\
\hline 5565.980 & 2 & 2782.990 & 28.956 & $.000^{\mathrm{a}}$ \\
\hline 5190.055 & 54 & 96.112 & & \\
\hline 10756.035 & 56 & & & \\
\hline
\end{tabular}

Tabel 3 menunjukkan nilai $F_{\text {hitung }}$ sebesar 28,956 dengan nilai signifikansi sebesar 0,000. Nilai signifikansi 0,000 lebih kecil dari tingkat alfa yang digunakan yaitu $5 \%$ atau 0,05 , maka ke 2 variabel bebas dalam penelitian ini mempunyai pengaruh yang positif dan signifikan terhadap kinerja pegawai $(\mathrm{Y})$, artinya naikturunnya nilai kinerja pegawai sangat ditentukan oleh naik turunnya ke 2 variabel 
bebas dalam penelitian ini, yaitu : kompetensi $\left(\mathrm{X}_{1}\right)$, dan disiplin kerja $\left(\mathrm{X}_{2}\right)$.

Dapat disimpulkan bahwa secara bersama-sama ke 2 variabel bebas yaitu kompetensi $\left(\mathrm{X}_{1}\right)$, dan disiplin kerja $\left(\mathrm{X}_{2}\right)$ berpengaruh signifikan terhadap kinerja pegawai (Y).

\section{Pengujian Hipotesis Secara Parsial (Uji t)}

Tabel 4

Uji Parsial (Uji t)

\begin{tabular}{|c|c|c|c|c|c|c|c|c|}
\hline \multirow{2}{*}{\multicolumn{2}{|c|}{ Model }} & \multicolumn{2}{|c|}{$\begin{array}{c}\text { Unstandardiz } \\
\text { ed } \\
\text { Coefficients }\end{array}$} & \multirow{2}{*}{$\begin{array}{c}\begin{array}{c}\text { Standar } \\
\text { dized } \\
\text { Coeffici } \\
\text { ents }\end{array} \\
\\
\text { Beta }\end{array}$} & \multirow[b]{2}{*}{$\mathrm{t}$} & \multicolumn{3}{|c|}{$\begin{array}{c}\text { Collinearity } \\
\text { Statistics }\end{array}$} \\
\hline & & B & $\begin{array}{l}\text { Std. } \\
\text { Error }\end{array}$ & & & Sig. & $\begin{array}{c}\text { Tolera } \\
\text { nce }\end{array}$ & VIF \\
\hline \multirow[t]{3}{*}{1} & (Constant) & 6.306 & 5.630 & & 1.120 & .268 & & \\
\hline & $\begin{array}{l}\text { Kompetens } \\
\text { i (X1) }\end{array}$ & .076 & .089 & .110 & .855 & .396 & .537 & 1.862 \\
\hline & $\begin{array}{l}\text { Disiplin } \\
\text { (X2) }\end{array}$ & .696 & .140 & .640 & 4.961 & .000 & .537 & 1.862 \\
\hline
\end{tabular}

Variabel Kompetensi Pegawai $\left(\mathrm{X}_{1}\right)$. Hasil uji statistik menunjukkan bahwa nilai $t_{\text {hitung }}$ sebesar 0,855 dengan nilai signifikan sebesar 0,396 . Nilai signifikansi lebih besar dari tingkat alpha yang digunakan 5\% $(0,05)$, maka keputusannya adalah menolak hipotesis alternatif $\left(\mathrm{H}_{\mathrm{a}}\right)$ dan menerima hipotesis nol $\left(\mathrm{H}_{\mathrm{o}}\right)$, bahwa secara parsial variabel kompetensi pegawai $\left(\mathrm{X}_{1}\right)$ mempunyai pengaruh yang positif namun tidak signifikan terhadap variabel kinerja pegawai. Artinya jika variabel kompetensi pegawaisemakin ditingkatkan maka kinerja pegawai juga akan meningkat tetapi tidak signifikan.

Variabel Disiplin Kerja $\left(\mathrm{X}_{2}\right)$. Hasil uji statistik menunjukkan bahwa nilai $\mathrm{t}_{\text {hitung }}$ sebesar 4,961 dengan nilai signifikan sebesar 0,000. Karena nilai signifikansi $(0,000)$ lebih kecil dari tingkat alpha yang digunakan 5\% $(0,05)$, maka keputusannya adalah menerima hipotesis alternatif $(\mathrm{Ha})$ dan menolak hipotesis nol (Ho), bahwa secara parsial variabel disiplin kerja mempunyai pengaruh yang positif dan signifikan terhadap variabel kinerja pegawai. Artinya bahwa jika disiplin kerja semakin baik maka kinerja pegawai juga akan semakin baik.

\section{PEMBAHASAN}

\section{Pengaruh Kompetensi Terhadap Kinerja Pegawai}

Hasil uji statistik menunjukkan bahwa nilai $t_{\text {hitung }}$ sebesar 0,855 dengan nilai signifikan sebesar 0, 396. Nilai signifikansi lebih besar dari tingkat alpha yang digunakan $5 \%(0,05)$, maka keputusannya adalah menolak hipotesis alternatif $\left(\mathrm{H}_{\mathrm{a}}\right)$ 
dan menerima hipotesis nol $\left(\mathrm{H}_{\mathrm{o}}\right)$, bahwa secara parsial variabel kompetensi pegawai $\left(\mathrm{X}_{1}\right)$ mempunyai pengaruh yang positif namun tidak signifikan terhadap variabel kinerja pegawai. Artinya jika variabel kompetensi pegawaisemakin ditingkatkan maka kinerja pegawai juga akan meningkat tetapi tidak signifikan. Fakta ini mengisyaratkan bahwa apabila kompetensi pegawai ditingkatkan atau meningkat, maka peningkatan kompetensi pegawai tersebut juga meningkat namun tidak secara serentak meningkatkan kinerja pegawai.

\section{Pengaruh Disiplin Kerja terhadap Kinerja Pegawai}

Hasil uji statistik menunjukkan bahwa nilai $t_{\text {hitung }}$ sebesar 4,961 dengan nilai signifikan sebesar 0,000. Karena nilai signifikansi $(0,000)$ lebih kecil dari tingkat alpha yang digunakan $5 \%(0,05)$, maka keputusannya adalah menerima hipotesis alternatif (Ha) dan menolak hipotesis nol (Ho), bahwa secara parsial variabel disiplin kerja mempunyai pengaruh yang positif dan signifikan terhadap variabel kinerja pegawai. Artinya bahwa jika disiplin kerja semakin baik maka kinerja pegawai juga akan semakin baik.

Fakta ini mengisyaratkan bahwa apabila disiplin kerja para pegawai ditingkatkan atau meningkat, maka peningkatan disiplin kerja tersebut secara serentak meningkatkan kinerja pegawaiDinas Pendidikan Pemuda dan Olahraga. Hasil penelitian ini sejalan dengan pendapat yang dikemukakan oleh Mangkuprawira (2007) bahwa disiplin kerja sangat mempengaruhi kinerja karyawan, hal ini disebabkan karena disiplin merupakan bentuk-bentuk latihan bagi karyawan dalam melaksanakan aturan-aturan perusahaan. Tanpa disiplin pegawai yang baik, sulit bagi organisasi mencapai hasil yang optimal. Sebaliknya, ketika tingkat kedisiplinan karyawan tinggi, target dari perusahaan akan dapat diselesaikan tepat pada waktunya. Disiplin kerja yang baik akan sangat berpengaruh kepada kinerja pegawai karena salah satu faktor penentu dari efektifitas kinerja adalah disiplin kerja.

\section{SIMPULAN}

Hasil uji statistik F menunjukkan bahwa secara bersama-sama (simultan) semua variabel bebas yang terdiri dari kompetensi pegawai (X1), dan disiplin kerja (X2) berpengaruh positif dan signifikan terhadap kinerja pegawai pada Dinas Pendidikan Pemuda dan Olahraga Kabupaten Sikka.

\section{DAFTAR PUSTAKA}

Boby, S, Aprizawati, \& Romadhoni (2020) Pengaruh Disiplin dan Kepemimpinan Diri dengan Kinerja Pegawai Direktorat Perkapalan dan Kelautan. Diakses melalui https://doi.org/10.31539/alignment.v3i1.1342

Epa, (2020). Kinerja Guru Dipengaruhi oleh Kompetensi Guru dan Kinerja Kepala Sekolah. Diakses melalui https://doi.org/10.31539/alignment.v3i2.1691 
Hamlan, D, (2015) Pengaruh Kompetensi, Disiplin dan Kompensasi terhadap Kinerja Pegawai Badan Pemberdayaan Perempuan dan Keluarga Berencana Daerah Provinsi Sulawesi Tengah. Thesis tidak di terbitkan. Tadulako : Program Pascasarjana Universitas Tadulako. Diakses melalui http://jurnal.untad.ac.id/jurnal/index.php/Katalogis/article/view/4250/3165

Mangkuprawira, (2007), Manajemen Sumber Daya Manusia Strategik, Jakarta : Penerbit Ghalia Indonesia.

Simanjuntak, J. P. (2011). Manajemen Dan Evaluasi Kinerja, Jakarta : Lembaga Penerbit Fakultas Ekonomi Universitas Indonesia.

Tony, S (2016) Pengaruh Disiplin dan Kompetensi Kerja terhadap Kinerja Karyawan CV Mangrove International Di Yogyakarta diakses melalui http://digilib.uinsuka.ac.id/20112/2/12240115

Undang-Undang Nomor 53 Tahun 2010 tentang Disiplin Pegawai Negeri Sipil. Jakarta: Kementrian Pegawai Negeri Sipil

Uswatun, N., H, (2019). Pengaruh Pelatihan Dan Disiplin Kerja Terhadap Kinerja Karyawan Menurut Perspektif Ekonomi Islam. Diakses melalui http://repository.radenintan.ac.id/7003/1/SKRIPSI.pdf 